\title{
Comparison of polychaete (Nereis spp.) ventilation in plastic tubes and natural sediment
}

\author{
Erik Kristensen
}

Institute of Genetics and Ecology, and Department of Zoophysiology, University of Aarhus, DK-8000 Aarhus C, Denmark

\begin{abstract}
Ventilation of Nereis virens and N. succinea was directly proportional to body weight when monitored in polyethylene tubes and natural sediment. Ventilation amplitude and total ventilation was about 3.8 and 1.9 times higher for $N$. succinea than for $N$. virens in both environments. Higher resistance in natural sediment, compared with that in plastic tubes, reduced ventilation amplitude in the former to only $1 / 2$ that in tubes. Duration of ventilation similarly showed a reduction to $1 / 3$ in natural sediment.
\end{abstract}

The sediment-water interface is an important site for the exchange of dissolved substances between the sediment and overlying water (e.g. Aller and Yingst, 1978). The amount of this exchange depends, among other things, on water movements across this surface. Many infaunal animals maintain contact with the water above the sediment by a burrow system through which water is pumped. Previous studies concerning ventilatory patterns in polychaetes were commonly performed with the animals inhabiting artificial burrows, i.e. glass or plastic tubes simulating the dimensions of natural burrows (Wells, 1949a; Wells and Dales, 1951; Dales, 1961; Seymour, 1972; Scott et al., 1976; Kristensen, 1981; Barrow and Wells, 1982; Kristensen, $1983 \mathrm{a}, \mathrm{b})$; only a few authors have attempted to assess ventilation when the animals were buried in natural sediment (Wells, 1949b; Mangum, 1964; Krüger, 1966; Aller and Yingst, 1978; Foster-Smith, 1978), probably due to methodical difficulties. Satisfactory comparisons of ventilation in tubes and in sediment are scarce, despite the fact that tube data on some occasions have been used as estimates for in situ population ventilation (Dworschak, 1981). This work compares ventilation of the polychaetes Nereis virens Sars and $N$. succinea (Frey and Leuckart) in tubes and in sediment, and evaluates the consequences of using plastic-tube ventilation data for in situ studies.

The errant polychaetes Nereis virens and $N$. succinea commonly live in large numbers in the intertidal zone of marine and brackish waters, normally in sediment of medium to high organic content (Muus, 1967; Kristensen, 1983a). The more or less permanent Ushaped burrows of these worms are ventilated by undulations of the body in a dorso-ventral plane.

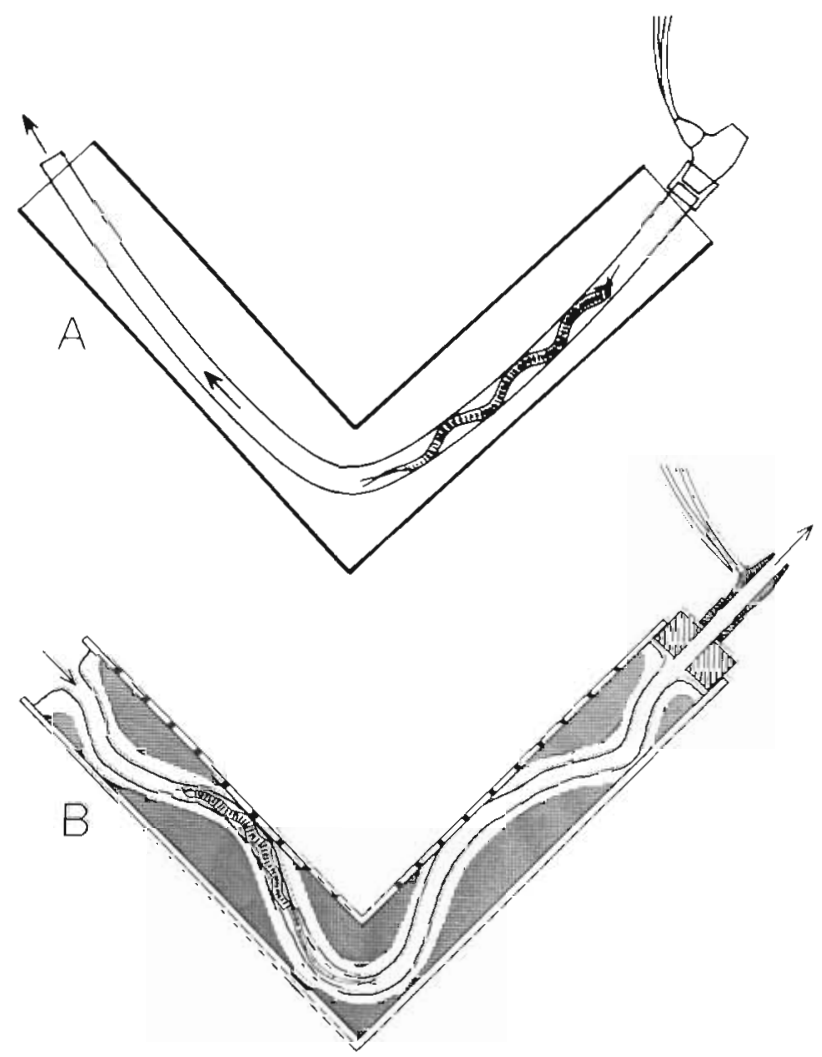

Fig. 1. Experimental setup for measurement of ventilation by Nereis spp. Cables from flow probe are connected to an electromagnetic flowmeter. (A) Worm in polyethylene tube, placed in a V-shaped Plexiglas tube; (B) Worm in natural sediment in a V-shaped Plexiglas tube 
Nereis virens and $N$. succinea were collected in the estuary Norsminde (Kysing) Fjord, Denmark (Muus, 1967). They were acclimated to experimental conditions, $16{ }^{\circ} \mathrm{C}$ and $20 \% \mathrm{~S}$ for at least $7 \mathrm{~d}$ before use. Experiments were performed in a 121 darkened aquarium. Worms for tube experiments were placed in polyethylene tubes of appropriate sizes $2 \mathrm{~d}$ before use (Kristensen, 1981) (Fig. 1A). Worms for sediment experiments were allowed to bury in sediment-filled, V-shaped Plexiglas tubes (i.d. $2.7 \mathrm{~cm}$ ) $5 \mathrm{~d}$ before use, in order to establish a natural burrow (Fig. 1B). Ventilation was measured with an electromagnetic flowmeter (Micron Instr. Corp.) and continuously recorded by a Hewlett-Packard 7132A recorder (Kristensen, 1981). Ventilation amplitude $\left(\dot{V}_{w}\right)$ was measured as average water flow, computed as the mean flow rate during periods of active ventilation. During ventilation periods the water flow was integrated and averaged, and expressed as $\mathrm{ml} \mathrm{min}^{-1}$. Average duration of ventilation $\left(D_{\mathrm{v}}\right)$ was determined as percent of the total measured time. Weight ranges were: $N$. virens, 0.5 to $5.0 \mathrm{~g} ; N$. succinea, 0.1 to $1.0 \mathrm{~g}$ wet wt.

Ventilation amplitude appeared to be directly proportional to body weight for both species and both experimental conditions ( $\mathrm{b}=0.98$ to 1.04 ) (Table 1 ; Fig. 2). This result is in agreement with reports of Kristensen (1981) on Nereis virens, N. succinea and $N$. diversicolor, and of Dworschak (1981) on the shrimp Upogebia pusilla. The correlation coefficient ( $\mathrm{r}$ ) of the weight relationship appeared for both species lower in tubes $(0.881$ to 0.930$)$ than in sediment $(0.936 \text { to } 0.974)_{\text {i }}$ this can be explained by a non-optimal fitting of worms in their tubes (Table 1). In sediment, however, the worms themselves optimized the dimensions of the burrows. Weight-specific ventilation amplitude for $N$. succinea was about 3.8 times higher than for $N$. virens in both environments, but due to the higher $D_{v}$ for the latter species the difference in total volume of water ventilated per unit time was only a factor $1.9 . \dot{V}_{w}$ in natural burrows appeared only about half that in tubes (53.4 to $56.4 \%$ ) for both species. Similarly, duration of ventilation $\left(D_{v}\right)$ in natural burrows was only 35.1 . $36.1 \%$ of the time spend ventilating in plastic tubes. The present low $\dot{V}_{w}$ in sediment is assumed a conse-

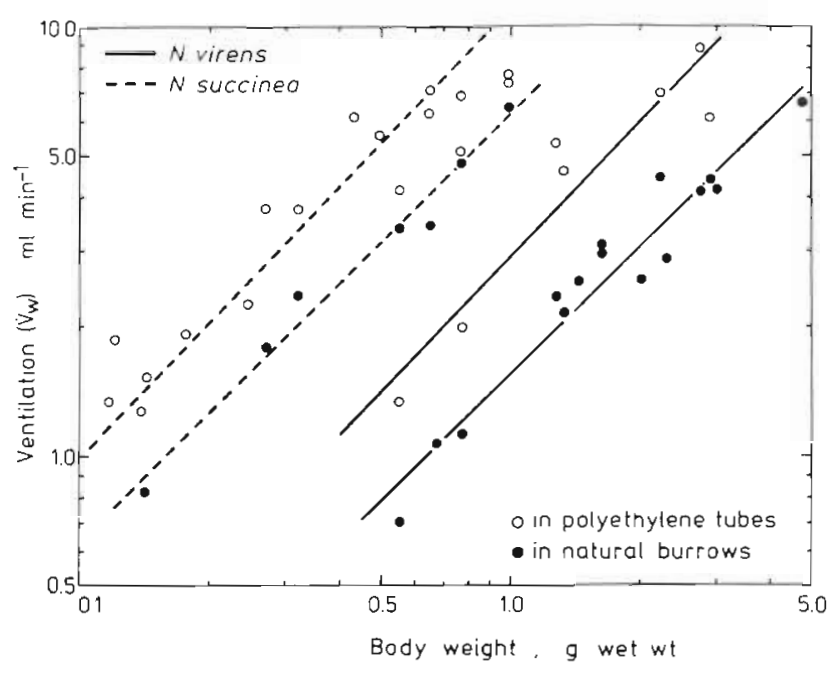

Fig. 2. Nereis virens and $N$. succinea. Relationship between

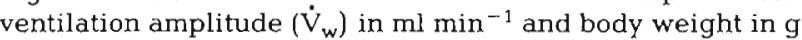
wet wt in polyethylene tubes and natural sediment

quence of higher resistance in the highly irregular natural burrows compared to the straight and smooth plastic tubes. The difference in ventilation amplitude and duration of ventilation observed here for the 2 experimental conditions contrast with the findings of Foster-Smith (1978) on $N$. diversicolor. He stated that the resistance of water movements in sediment burrows was only slightly higher than in tubes, since no difference appeared in his ventilation data between the two environments. Unfortunately, no weight data of the worms were available. However, Gust and Harrison (1981) found that the mechanical work dissipated by the friction losses within the burrow system of the shrimp Alpheus mackayi was of the same order of magnitude as the kinetic energy of the ejected water. The much shorter time spent ventilating in sediment compared to tubes was rather surprising. If the ventilatory current produced by nereids is only a result of respiratory needs, one would expect the opposite response, since worms in tubes have only to provide oxygen for respiration ( + additional microbial respiration of mucus lining the tube walls; Kristensen, 1983a), whereas in natural burrows they have to provide both for their own and a considerable amount of sediment respiration (Sørensen et al., 1979). Presumably, ven-

Table 1. Nereis virens and $N$. succinea. Relationship between ventilation $\left(\dot{V}_{w}\right)$ and body weight $(M) . V_{w}=a x M^{0}$, $=$ correlation coefficient, $n=$ number of observations. Comparison between worms in polyethylene tubes and in natural burrows. $D_{v}$ duration of ventilation periods in $\%$ of total time; $\dot{V}_{w t}$ and $D_{v t}$ in tubes; $\dot{V}_{w b}$ and $D_{v b}$ in burrows

\begin{tabular}{llrrrrrrr}
\hline Species & Treatment & $\mathrm{a}$ & $\mathrm{b}$ & $\mathrm{r}^{2}$ & $\mathrm{n}$ & $\mathrm{D}_{\mathrm{v}}(\%)$ & $\dot{\mathrm{V}}_{\mathrm{wb}} / \dot{\mathrm{V}}_{\mathrm{wt}}$ & $\mathrm{D}_{\mathrm{vb}} / \mathrm{D}_{\mathrm{vt}}$ \\
\hline$N$ virens & Burrow & 1.56 & 0.98 & 0.936 & 15 & $20.4 \pm 7.9$ & 0.534 & 0.351 \\
$N$. virens & Tube & 2.92 & 1.03 & 0.881 & 7 & $58.1 \pm 15.0$ & \\
$N$. succinea & Burrow & 6.17 & 0.99 & 0.974 & 7 & $10.1 \pm 1.9$ & 0.564 & 0.361 \\
$N$. succinea & Tube & 10.94 & 1.04 & 0.930 & 17 & $28.0 \pm 10.3$ & & \\
\hline
\end{tabular}


tilatory currents of nereids are not solely respiratory, but additionally remove metabolic and other potentially poisonous wastes from the burrow. However, the high $D_{v}$ observed in tubes suggests that the worms were in a condition of stress (or 'annoyance'), compared to their counterparts in natural burrows.

The laboratory method presented here for ventilation measurements in natural sediment approximates in situ rates; however, if data of nereid ventilation in tubes are used for in situ determinations, the rates would be about 6 times too high. It must be concluded that measurements of Nereis ventilation in plastic tubes cannot be extrapolated to in situ pumping rates; they should preferably be used for comparative investigations.

Acknowledgements. This study was supported by Grant No. 1979-22/523-42 from the University of Aarhus.

\section{LITERATURE CITED}

Aller, R. C., Yingst, J. Y. (1978). Biogeochemistry of tubedwellings: a study of the sedentary polychaete Amphitrite ornata (Leidy). J. mar. Res. 36: 201-254

Barrow, M. J., Wells, R. M. G. (1982). Ventilation and oxygen extraction in an arenicolid polychaete. Comp. Biochem. Physiol. 73 A: 491-495

Dales, R. P. (1961). Oxygen uptake and irrigation of the burrow by three terebellid polychaetes: Eupolymnia, Thelepus and Neoamphitrite. Physiol. Zool. 34: 306-311

Dworschak, P. C. (1981). The pumping rates of the burrowing shrimp Upogebia pusilla (Petagna) (Decapoda: Thalassinidea). J. exp. mar. Biol. Ecol. 52: 25-35

Foster-Smith, R. L. (1978). An analysis of water flow in tubeliving animals. J. exp. mar. Biol. Ecol. 34: 73-95

Gust, G., Harrison, J. T. (1981). Biological pumps at the sediment-water interface: mechanistic evaluation of the alpheid shrimp Alpheus mackayi and its irrigation pattern. Mar. Biol. 64: 71-78

Kristensen, E. (1981). Direct measurement of ventilation and oxygen uptake in 3 species of tubicolous polychaetes (Nereis spp.). J. Comp. Physiol. 145: 45-50

Kristensen, E. (1983a). Ventilation and oxygen uptake by three species of Nereis (Annelida: Polychaeta). I. Effects of hypoxia. Мar. Ecol. Prog. Ser. 12: 289-297

Kristensen, E. (1983b). Ventilation and oxygen uptake by three species of Nereis (Annelida: Polychaeta). II. Effects of temperature and salinity changes. Mar. Ecol. Prog. Ser. 12: $299-306$

Krüger, F. (1966). Messungen der Pumptätigkeit von Arenicola marina L. im Watt. Helgoländer wiss. Meeresunters. 11: 70--91

Mangum, C. P. (1964). Activity patterns in metabolism and ecology of polychaetes. Comp. Biochem. Physiol. 11: 239-256

Muus, B. J. (1967). The fauna of Danish estuaries and lagoons. Distribution and ecology of dominating species in the shallow reaches of the mesohaline zone. Meddr Danm. Fisk-og Havunders., ny ser. 5: 3-316

Seymour, M. K. (1973). Effects of temperature change on irrigation rate in Arenicola marina (L.). Comp. Biochem. Physiol. 43 A: 553-564

Scott, D. M., Mazurkiewicz, M., Leeman, P. (1976). The longterm monitoring of ventilation rhythms of the polychaete annelid Nereis virens Sars. Comp. Biochem. Physiol. 53 A: $65-68$

Sørensen, J., Jørgensen, B. B., Revsbeck, N. P. (1979). A comparison of oxygen, nitrate, and sulfate respiration in coastal marine sediments. Microb. Ecol. 5: 105-115

Wells, G. P. (1949a). Respiratory movements of Arenicola marina $\mathrm{L}$.: Intermittent irrigation of the tube, and intermittent aerial respiration. J. mar. biol. Ass. U. K. 28: 447-464

Wells, G. P. (1949b). The behavior of Arenicola marina L. in sand and the role of spontaneous activity cycles. J. mar biol. Ass. U. K. 28: 465-478

Wells, G. P., Dales, R. P. (1951). Spontaneous activity patterns in animal behaviour: the irrigation of the burrow in the polychaetes Chaetopterus variopedatus Renier and Nereis diversicolor O. F. Müller. J. mar. biol. Ass. U.K. 29: $661-680$

Accepted for printing on April 9, 1983 